\title{
Entre imagem e palavra: entrevista com a professora Márcia Arbex
}

\author{
Márcia Arbex ${ }^{\mathrm{i}}$ \\ Entrevistadores: \\ Thayane Verçosa ${ }^{\text {ii }}$ \\ Lais Alves ${ }^{\text {iii }}$
}

A sólida e admirável trajetória da professora Márcia Arbex, centrada em temas como literatura, artes e mídia, e sua reflexão sobre as relações entre as obras escritas e/ou visuais, justifica por si só a sua presença como entrevistada neste número da Palimpsesto. Graduada em Letras (Português/Francês) pela Universidade Federal do Rio de Janeiro, a professora fez Doutorado em Literatura e Civilização Francesas na Universidade de Sorbonne Nouvelle Paris 3, realizou três pós-doutorados, sendo o mais recente no Centro de Pesquisa Thalim dessa mesma universidade, e os demais pela Universidade Federal do Rio de Janeiro e pela Universidade Paris 7 - Denis Diderot. Atualmente, ela é Professora Titular da Universidade Federal de Minas Gerais. Seu projeto de pesquisa mais recente, intitulado "Sobrevivências da imagem na escrita: tempo e memória em narrativas contemporâneas", iniciado em 2020, é um dos exemplos de reflexão da nossa entrevistada sobre as relações entre literatura e outras artes. Há mais de duas décadas, ela vem coordenando diferentes projetos de pesquisa que tematizam essa relação, bem como publicando artigos e livros sobre o assunto,

\footnotetext{
${ }^{\text {i }}$ Professora Titular da Faculdade de Letras da Universidade Federal de Minas Gerais, onde leciona no Programa de Pós-Graduação em Estudos Literários e na Graduação em Letras (Licenciatura e Bacharelado em Francês). Doutora em Literatura e Civilização Francesas pela Université Sorbonne Nouvelle - Paris 3 (1992) e graduada em Letras - Licenciatura Plena em Português-Francês pela Universidade Federal do Rio de Janeiro (1984). Realizou Pós-Doutorado na Université Paris 7 - Denis Diderot (2003) e na Universidade Federal do Rio de Janeiro (2010).

ii Doutoranda em Literatura Brasileira pela Universidade do Estado do Rio de Janeiro. Bolsista Capes. thayanevercosa@hotmail.com

iii Mestranda em Teoria da Literatura e Literatura Comparada pela Universidade do Estado do Rio de Janeiro (UERJ). Bolsista CAPES. 1ais.alvessouza@yahoo.com.br
} 
como, por exemplo, Sobrevivências da imagem na escrita: Michel Butor e as artes (2020).

É com enorme satisfação que publicamos esta entrevista com a professora Márcia Arbex, que aceitou prontamente o nosso convite, e foi muito receptiva às questões que lhe propusemos. Gostaríamos de ressaltar que foi um prazer conhecer mais a trajetória admirável da nossa entrevistada, e que aprendemos muito com a sua produção e reflexões sobre um assunto tão fundamental não apenas para os estudiosos de literatura, mas também para os de outras áreas. Desejamos a todos uma excelente leitura.

\section{PALIMPSESTO}

1) Há mais de duas décadas a senhora vem coordenando diferentes projetos de pesquisa que tematizam a relação entre literatura e outras artes, tendo publicado diversos textos sobre o assunto. Considerando a sua sólida produção na área, gostaríamos de saber: (a) como se deu o seu interesse acadêmico pela relação entre diferentes artes?; (b) como anda o campo dos estudos intermidiáticos, dentro e fora do Brasil?; (c) na sua opinião, que autores são incontornáveis, hoje, para quem deseja se aprofundar no assunto?

\section{MÁRCIA ARBEX}

Primeiro, gostaria de agradecer às editoras pelo convite para esta entrevista e pela leitura atenta de alguns de meus artigos.

Ao final da minha Graduação em Letras, cursada na UFRJ, como eu me interessava tanto pela literatura quanto pelas artes, procurei elaborar um projeto de pesquisa de pós-graduação que tivesse por foco a interação entre essas duas formas de expressão artística. Assim, minha tese de doutorado investigou a função da escrita nas artes visuais no período das vanguardas históricas, com o título: Da imagem da letra à picto-poesia: estudo sobre a função da escrita nas artes visuais (1910-1930), tese que foi defendida na Université de Paris 3 e validada pela UFRJ na área de Semiologia. Mais tarde, já como professora do Programa de Pós-Graduação em Estudos Literários da UFMG e pesquisadora do CNPq, desenvolvi diversos projetos nessa mesma linha de pesquisa, chamada de Literatura e outras artes (hoje, Literatura, outras artes e mídias), de modo a abarcar as diferentes modalidades de diálogo entre a literatura e as artes 
visuais. Iniciei investigando a iconicidade da escrita e a visualidade das palavras nas artes visuais, a intericonicidade e a colagem, os escritos de artista, para em seguida estudar a presença da imagem na literatura, os processos de transposição intersemiótica, seja como ilustração, iconotexto, écfrase; enfim, me interessei pelos livros de artista, os livros-objetos e outras formas de diálogo interartístico.

Essas pesquisas levam em conta, necessariamente, o debate histórico sobre as dimensões do visível e do legível, bem como sua teorização, que é de longa data. Os estudos sobre a intermidialidade decorrem dessa longa tradição que vem da doutrina do ut pictura poesis, passa pela crítica de arte de Diderot nos Salões e pela discussão sobre as fronteiras entre a pintura e a poesia inaugurada por Lessing, pelas "correspondências entre as artes" e pelos estudos semiológicos sobre a noção ampliada de Texto, até os Estudos Interartes. A revisão do próprio conceito de arte, operada no século XX, conduziu à revisão do estatuto da imagem em sua relação com as palavras. Logo, para além da comparação entre a pintura e a poesia, para além do paragone, novos tipos de expressão literária e estética até então excluídos dos estudos comparativos interartes, passaram a ser investigados pela sua importância enquanto fenômenos culturais contemporâneos, tanto quanto pelos desafios que colocam para a recepção.

Os estudos sobre a intermidialidade vêm, de fato, se consolidando no Brasil por meio da realização de eventos, de divulgação de pesquisas, de publicações de livros e dossiês temáticos de revistas, bem como de traduções de textos de referência. Os pesquisadores que se debruçam sobre os fenômenos intermidiáticos abrem perspectivas para inclusão de um campo estético e tecnológico mais vasto, como as mídias televisivas e digitais, a arte performática, a poesia digital, por exemplo, e não apenas as artes ditas convencionais. O número crescente de produções artísticas e literárias marcadas pela hibridez, pela mescla de gêneros, pela consciência de sua materialidade, solicita, portanto, continuamente, uma revisão de conceitos e abordagens teóricas e metodológicas. Na verdade, se considerarmos que não existe uma mídia "pura", e que esse fenômeno da hibridez sempre existiu, para a análise dos processos criativos a questão que se coloca é de ordem metodológica e teórica, bem como suas implicações sociológicas, históricas e culturais.

Existem vários centros de pesquisa voltados para esse tipo de objeto de investigação, com orientações teóricas diversas, mas todos têm em comum, de alguma 
forma, o estudo sobre a relação palavra e imagem. Posso citar alguns deles, dos quais faço parte, considerando que as publicações de seus membros são relevantes para aqueles que se interessam por essa linha de pesquisa. No Brasil, o Grupo Intermídia, criado em 2005 pela Profa. Thais Diniz com a colaboração do Prof. Claus Clüver, cuja produção é uma referência no assunto, e o GT da ANPOLL Intermidialidade. São também incontornáveis, a meu ver, os trabalhos desenvolvidos pelos membros da IAWIS- International Association of Word and Image, do CRIalt - Centre de Recherches Intermédiales sur les arts, les lettres et les techniques, da Universidade de Montreal, bem como do CEEI - Centre d'Études sur l'Écriture et l'Image, rede de pesquisa internacional sobre a escrita, a tipografia, a ilustração. Mantemos ainda contato com pesquisadores de universidades estrangeiras como a Freie Universität Berlin, Florida University ou a Linnæus University na Suécia ${ }^{1}$.

\section{PALIMPSESTO}

2) No artigo "A imagem escrita da infância" (2006), ao comentar La mer écrite [O mar escrito], "um pequeno álbum composto de textos e de fotografias, os primeiros de autoria de Marguerite Duras, as fotos de Hélène Bamberger" (ARBEX, 2006, p. 109), diante de uma das fotografias, ressaltando como o texto e a imagem estão posicionados lado a lado, a senhora comenta: "Neste álbum, o texto à esquerda e a fotografia, à direita, ocupam o centro das páginas respectivas, não ultrapassando os limites invisíveis da mancha gráfica. Não há primazia de um sobre o outro, ambos são apresentados simultaneamente e transformam as relações entre a palavra e a imagem, antes hierarquizadas na ilustração. A fotografia não ilustra o texto, o texto não é o comentário da imagem: eles se completam" (Ibid., p. 110). Poderíamos comparar esse trabalho com, por exemplo, uma das obras mais famosas da fotógrafa Maureen Bisilliat, intitulada $A$ João Guimarães Rosa (1969). Nela, a autora fotografa o sertão mineiro e alia suas fotos a trechos de Grande sertão: veredas (1956), publicados junto às imagens (às vezes abaixo, acima, ou ao lado delas), de forma aproximada ao que é apresentado em La mer écrite [O mar escrito]. Considerando que o ensaio de Bisilliat foi motivado pela leitura do romance, com a citação de trechos que não foram originalmente concebidos em sua relação com as imagens, é possível pensar que na obra da fotógrafa também há uma relação de complementaridade e igualdade entre as imagens e os trechos citados? $\mathrm{O}$ fato de que ela tenha se inspirado na leitura de um romance implicaria uma hierarquia entre texto e imagem? A João Guimarães Rosa seria um caso de tradução intersemiótica? 


\section{MÁRCIA ARBEX}

Em ambos os casos podemos falar em fotoliteratura, no sentido dado por JeanPierre Montier, mas do ponto de vista da produção os trabalhos me parecem distintos. Marguerite Duras e Hélène Bamberger realizam inicialmente um trabalho em conjunto, de colaboração, durante aquele verão de 1980 em Trouville; o nome da escritora e o da fotógrafa aparecem, aliás, na capa do livro. No que se refere ao álbum $A$ João Guimarães Rosa, embora o escritor brasileiro tenha inicialmente contribuído ao projeto (como é dito na apresentação do livro na página da editora, Bisilliat mostrava as fotos para Rosa ao voltar de suas viagens pelo sertão, e ele anotava os nomes de lugares e pessoas no verso das imagens) $)^{2}$, não me parece que se trata do mesmo tipo de colaboração na produção da obra. O fato de o ensaio fotográfico de Bisilliat ter sido motivado pela leitura do romance de Guimarães Rosa pode, a meu ver, ser interpretado como uma transposição intersemiótica, do verbal para o visual, uma vez que o texto precede as imagens, que as fotos foram motivadas pelo romance. No que se refere à presença das citações extraídas de Grande sertão, acredito que seja preciso levar em consideração outras informações sobre a produção da obra, seja por meio de entrevistas com a fotógrafa, paratextos como prefácios ou outro material que permita avaliar, por exemplo, como foi feita a escolha dos trechos literários. Assim poderíamos ter acesso ao processo criativo da obra. Além de considerar também o papel do editor, sua participação na concepção do trabalho editorial, nas escolhas gráficas, no formato do livro, na disposição das fotos e imagens, tudo que envolve a materialidade do objeto livro.

Do ponto de vista da recepção, contudo, pode-se considerar que a relação de complementaridade observada no livro de Duras e de Bamberger é similar à de Bisilliat. O leitor tem em mãos um objeto híbrido (uma combinação de mídias), em que o texto e a imagem estão reunidos em um mesmo suporte e ocupam simultaneamente a página, tendo em vista a disposição gráfica escolhida, mas mantém suas diferenças midiáticas. Assim, há um diálogo entre o que se vê e o que se lê, um trânsito entre o visível e o legível, ainda que a imagem tenha maior impacto pelas suas dimensões com relação ao espaço ocupado pelo texto. As citações de Rosa não são comentários das fotografias, nem as fotografias são ilustrações dos trechos do romance, no sentido que a palavra "ilustração" tinha até o início do século XIX, ou seja, uma "imagem do livro" destinada 
a acompanhar o texto impresso, de natureza funcional, visando explicar, comentar ou esclarecer. Essa relação hierarquizada foi colocada em questão, transgredida desde o final do século XIX, justamente pelos artistas e poetas, que passaram a trabalhar juntos, dando origem a belas produções, os "livros de diálogo", nas palavras de Michel Butor ou Yves Peyré, os "livros duplos", como diz Anne-Marie Christin, nos quais o intervalo e a oscilação entre o visível e o legível também são criadores de sentidos.

\section{PALIMPSESTO}

3) Em seu artigo "As metáforas picturais de René Magritte" (2007), comentando "a distância que existe entre a representação de uma coisa e a coisa real, subtendendo ainda que não há relação de fato entre um objeto real e a imagem (ou o nome) que o representa, a relação é arbitrária e convencional" (ARBEX, 2007, p. 157-158), a senhora pondera que "[o] quadro que melhor traduz esta ideia é La Trahison des images (A traição das imagens), em que uma legenda (Ceci n'est pas une pipe) acompanha a imagem de aparência realista do objeto 'cachimbo', imitando aquelas encontradas nos manuais escolares", de modo que "o conteúdo da inscrição que parece, a princípio, contradizer a imagem que mostra um cachimbo, visa de fato evidenciar que as imagens não são tangíveis como a linguagem" (Ibid., p. 158). Desde sua criação, La Trahison des images tem se tornado uma fonte de inspiração de pastiches diversos, com as mais distintas finalidades críticas. Parece haver um subgrupo desses pastiches, que poderíamos classificar como político, no qual a imagem de um presidente vem acompanhada da legenda: “Ceci n'est pas un président". Donald Trump, Michel Temer, Jair Bolsonaro e Nicolás Maduro são algumas figuras referenciadas em tais pastiches. Nesses casos, poderíamos considerar que eles ainda "visa[m] de fato evidenciar que as imagens não são tangíveis como a linguagem"? Ao retomar uma obra clássica questionadora do caráter representacional da imagem e imbuí-la de uma dimensão política com intenção crítica, que novos sentidos são agregados a ela? A ampla difusão desse tipo de pastiche afeta, de algum modo, o sentido crítico da obra original?

\section{MÁRCIA ARBEX}

De fato, essa tela de Magritte é uma das mais conhecidas do artista belga, a que gerou mais releituras desde sua criação no final da década de 1920. O estudo de Michel Foucault sobre as diferentes versões de La Trahison des images, fruto das trocas entre o filósofo e o artista em torno de questões que os preocupam, "as palavras e as coisas", tornou-se um texto de referência desde sua publicação em 1973, fato que contribuiu 
muito para essa retomada da inscrição "Isto não é um cachimbo", quase um aforismo, para servir aos mais diversos propósitos, seja artístico, político ou humorístico. Muitas interpretações foram feitas sobre essa relação aparentemente paradoxal entre a inscrição e a imagem nesse quadro, de modo que não se trata de retomá-las aqui. Mas é importante lembrar o contexto em que a obra foi produzida e as preocupações de Magritte à época, quando praticava esse método de associações de palavras a figuras visando a criação de um efeito poético perturbador, um estranhamento entre a percepção dos objetos e o modo como são nomeados. Isso evidencia ainda a problemática, cara a Magritte, da semelhança e da desconstrução das convenções da representação. Magritte trabalha nessa tela como um filósofo da linguagem e, por que não, da imagem. Nesse ponto, a retomada irônica da célebre frase "Isto é um cachimbo", por meio do elo pastiche, transpondo-a para diferentes contextos, atualiza seu aspecto crítico, desconstrutivo, mas em outros termos, uma vez que a questão não é mais da tangibilidade da imagem ou da linguagem. As implicações políticas decorrentes da retomada crítica do princípio da associação texto-imagem, a meu ver, de fato, ampliam o alcance da obra original.

\section{PALIMPSESTO}

4) No ensaio hoje clássico, "O efeito de real" (1968), Roland Barthes diferencia o verossímil moderno do antigo, mostrando, em um movimento contrastivo, que a descrição antiga era marcada por uma finalidade estética, enquanto a moderna estaria submetida a uma finalidade referencial, realista. Entretanto, ao analisar Madame Bovary, obra de um autor reputadamente realista, ele percebe como a descrição flaubertiana é marcada por um entrecruzamento da finalidade estética e da referencial. Não nos parece exagero dizer que o mesmo convívio entre os diferentes tipos de descrições seria encontrado também, por exemplo, em Vidas secas, de Graciliano Ramos, romance considerado por Alfredo Bosi (2015, p. 431) como "obra-prima da sobriedade formal". Seria a presença das descrições estéticas ("ecfrásticas”, segundo Barthes) em obras realistas um dos casos de correspondências entre literatura e pintura? Como essa questão barthesiana poderia ser recolocada nos termos dos estudos intermidiáticos contemporâneos?

\section{MÁRCIA ARBEX}


Não há dúvida de que a écfrase é um topos recorrente nos estudos das correspondências entre literatura e pintura e um operador relevante nas pesquisas sobre o texto e a imagem, principalmente quando toma por objeto uma obra artística. Como exercício retórico, como se sabe, a écfrase tem suas origens na Antiguidade, mas ainda hoje é objeto de reflexão por parte dos pesquisadores, de modo que a bibliografia sobre esse assunto é muito vasta, e implica questões terminológicas e teóricas por vezes controversas. Recentemente, publiquei um artigo sobre a presença de descrições de obras de arte, também chamadas de "tableaux d'auteurs" em narrativas contemporâneas de expressão francesa; nas disciplinas que ministro no Programa de Pós-graduação em Estudos Literários- Poslit, esse topos também é objeto de análise, além de figurar no programa de muitos eventos na área ${ }^{3}$.

A ekphrasis, termo grego definido por manuais retóricos como um tropo, uma das figuras de pensamento, é equivalente à descriptio, descrição em latim. Muito resumidamente, podemos dizer que a écfrase é inicialmente uma técnica de descrição retórica cuja finalidade é detalhar algo em palavras, de forma minuciosa, seja a descrição de pessoas, ações, lugares, animais ou objetos reais ou fictícios. No entanto, estudos e traduções dos séculos XVIII e XIX favoreceram a retomada do termo no sentido de "descrição literária", o que resultou na redefinição do termo, que passou a designar mais especificamente ainda a "descrição literária de obra de arte", ou ainda uma "transposition d'art", colocando em evidência a relação entre literatura e artes visuais. Roland Barthes participa desse debate no campo das teorias narrativas do século XX defendendo a descrição como um elemento capital da diegese, em particular nos autores do século XIX, como Flaubert, acima citado. Em oposição a uma concepção que considera a descrição como "detalhe inútil", ornamental, por ameaçar a coerência da obra, Barthes propõe uma visão mais moderna e semiológica: o detalhe é um elemento importante que participa da criação de um "efeito de real" que dá à descrição uma dimensão histórica, para além de sua função estética apenas. Lembro que, em $S / Z$, Roland Barthes já havia proposto eliminar a diferença entre a literatura e a pintura, que seria puramente de meio material, renunciar à pluralidade das artes para afirmar a "pluralidade dos textos", como um primeiro passo para introduzir a discussão sobre os objetos artísticos como objetos de cultura no campo dos estudos comparatistas. Essa mudança de paradigma teve grande repercussão para o entendimento da écfrase. 
Os estudiosos do campo da intermidialidade, aliás, têm se dedicado cada vez mais a essa noção de longa tradição, incluindo-a dentre dos procedimentos de transformação de mídia. Isso porque a écfrase é considerada um fenômeno transmidiático e, ainda que a pintura seja a principal fonte para as descrições literárias de obras de arte, nota-se uma crescente preocupação em abarcar outros tipos de manifestação artística, tais como pinturas não representativas, fotografia, instalação, arquitetura, música, cinema. Para além do campo dos Estudos Interartes, o estudo da écfrase se expande para objetos compostos em diferentes mídias, inclusive as mídias digitais próprias da atualidade ${ }^{4}$.

\section{PALIMPSESTO}

5) O projeto de pesquisa mais recente coordenado pela senhora, "Sobrevivências da imagem na escrita: tempo e memória em narrativas contemporâneas", iniciado em 2020, é descrito como um projeto "de natureza transdisciplinar, [que] visa articular a investigação teórica sobre a interação entre a escrita e a imagem, a literatura e as artes, a produções literárias de autores contemporâneos, em particular de expressão francesa tais como Michel Butor, Jean-Marie Gustave Le Clézio, Patrick Modiano, Michel Houllebecq, Pascal Quignard e Georges Perec". Que áreas do conhecimento são envolvidas nesse projeto transdisciplinar? Como as noções de escrita e de imagem são articuladas no projeto? Que tipos de ferramentas de investigação pretende-se produzir com o desenvolvimento do projeto? Há a intenção de ampliar o projeto para autores contemporâneos que não sejam de expressão francesa?

\section{MÁRCIA ARBEX}

Meu projeto mais recente envolve as áreas de Literatura Comparada, Teoria Literária, Literatura de Expressão Francesa, mas também a História e a Filosofia da arte, a Antropologia, a História da escrita e a Edição. Essa pesquisa examina a interação entre as artes para constituir um quadro teórico para a análise de narrativas contemporâneas que transitam por essa zona fronteiriça entre a escrita e a imagem, e produzir ferramentas de investigação que possam, sim, ser utilizadas em análises de autores contemporâneos de modo geral, e não apenas da Literatura Francesa. Minha hipótese é que, para determinados autores ou em certas obras, a imagem, ancorada em diferentes mídias e sobre diferentes suportes, torna-se um alicerce midiático privilegiado da escrita. A obra de Alain Robbe- 
Grillet ou a de Michel Butor, na qual me detive mais recentemente, são exemplares a esse respeito 5 . A produção de Michel Butor é particularmente significativa. A partir de um mapeamento das modalidades de relação entre a escrita e a imagem em sua vastíssima obra, identificamos diversos iconotextos: as descrições de obras de arte nos romances, os jogos tipográficos, a fotoliteratura e os livros de diálogo realizados em colaboração com artistas, tendo como horizonte os modos de sobrevivência da imagem na escrita. O estudo parte das noções de "alicerce midiático" de Walter Moser; iconotexto, de Liliane Louvel; "iconicidade da escrita" e "pensamento da tela", propostas por Anne-Marie Christin e por teóricos que, como ela, entendem a escrita como uma entidade mista, formada pelo verbal e pelo visual; recorro ainda à concepção de imagem e de tempo de Georges Didi-Huberman, entre outros teóricos. As noções de escrita e de imagem são os principais operadores para esse estudo, além dos conceitos de colagem e de montagem, que são dispositivos críticos relevantes para entender não apenas as técnicas compositivas dos textos, mas seus efeitos de conhecimento visual, da ação de temporalidades múltiplas envolvidas na sobrevivência da imagem como fato de memória, seja ela individual ou coletiva.

\section{Referências}

ARBEX, Márcia. A imagem escrita da infância. Revista do CESP, Belo Horizonte, v. 26, n. 35, p. 107-123, jan./jun. 2006. Disponível em: http://www.periodicos.letras.ufmg.br/index.php/cesp/article/view/6651/5651. Acesso em: 27 jun. 2021.

ARBEX, Márcia. As metáforas picturais de René Magritte. Letras, Santa Maria, n. 34, jun. 2007. Disponível em: https://periodicos.ufsm.br/letras/article/view/11945. Acesso em: 3 jul. 2021.

BARTHES, Roland. O efeito de real. In: Laranjeira. São Paulo: Brasiliense, 1988. p. 158-165.

O rumor da língua. Tradução Mário

BOSI, Alfredo. Tendências contemporâneas: Graciliano Ramos. In: História concisa da literatura brasileira. 50. ed.. São Paulo: Editora Cultrix, 2015. p. 428-432. 


\begin{abstract}
${ }^{1}$ No Brasil, são inúmeras as publicações sobre o assunto; indicarei a página do Grupo Intermídia onde se encontra uma lista não exaustiva desses textos:

http://www.letras.ufmg.br/padrao_cms/?web=intermidia\&lang=1\&page=2657\&menu=1685\&tipo=1.

Para aqueles que possam se interessar, indico as páginas desses centros de pesquisa no exterior: https://www.iawis.org/; https://crialt-intermediality.org/eng/; https://ceei.hypotheses.org/. Cf. ainda ARBEX, M. Poéticas do visível: uma breve introdução. In: ARBEX, Márcia (org.) Poéticas do Visível: ensaios sobre a escrita e a imagem. Belo Horizonte: FALE/ PÓSLIT, 2006.

${ }^{2}$ Disponível em: https://ims.com.br/2018/10/04/fotografia-e-literatura-nos-livros-de-maureen-bisilliat-ajoao-guimaraes-rosa/.

${ }^{3}$ Cf. ARBEX, M. Contemporary tableaux d'auteurs in Michel Houellebecq's and Michel Tournier's Novels. In: Text - Image - Music: Crossing the Borders. Intermedial Conversations on the Poetics of Verbal, Visual and Musical Texts, ed. by Andrzej Pawelec and Grzegorz Szpila. Peter Lang Edition, 2020.

4 Para a discussão sobre a écfrase, dentre muitos outros artigos, cf. Clüver, Claus. "Ekphrasis Reconsidered: On Verbal Representations of Non-Verbal Texts." In: Lagerroth, Ulla-Britta, Hans Lund and Erik Hedling (eds.), Interart Poetics: Essays on the Interrelations between the Arts and Media. Amsterdam, Atlanta: Rodopi, 1997, p. 19-33; Webb, Ruth. "Ekphrasis Ancient and Modern: The Invention of a Genre." Word \& Image: A Journal of Verbal/Visual Enquiry, 15: 1, 1999; Vouilloux, Bernard. Tableaux d'auteurs. Après l'Ut pictura poesis. Saint-Denis: Presses Universitaires de Vincennes, 2004.
\end{abstract}

${ }^{5}$ Cf. ARBEX, M. Sobrevivências da imagem na escrita: Michel Butor e as artes. Belo Horizonte: Editora Relicário, 2020; ARBEX, M. Alain Robbe-Grillet e a pintura: jogos especulares. Belo Horizonte: Editora UFMG, 2013. 


\title{
Between Image and Word: An Interview with Márcia Arbex
}

\author{
Márcia Arbex ${ }^{\mathrm{i}}$ \\ Entrevistadores: \\ Thayane Verçosa ${ }^{\text {ii }}$ \\ Lais Alves ${ }^{\text {iii }}$
}

Centered on themes such as literature, arts, and media, and reflecting mostly on the relations between written and/or visual works, Professor Márcia Arbex's solid and admirable trajectory justifies her presence as an interviewee in this issue of Palimpsesto. A graduate in Literature (Portuguese/French) from Federal University of Rio de Janeiro, she has a $\mathrm{PhD}$ in French Literature at Sorbonne University Paris 3 and has three postdoctoral degrees, the most recent also from the Research Center Thalim in Sorbonne Paris 3, one from the Federal University of Rio de Janeiro, and another from the Paris 7 University - Denis Diderot. She is currently a professor at the Federal University of Minas Gerais. "Sobrevivências da imagem na escrita: tempo e memória em narrativas contemporâneas", her most recent research project started in 2020 and is an example of our interviewee's reflection on the relations between literature and other arts. For over two decades she has been coordinating different research projects about this relation, as well as publishing articles and books on the subject such as Sobrevivências da imagem na escrita: Michel Butor e as artes (2020).

\footnotetext{
${ }^{i}$ Professor at the Graduate Program in Literary Studies and in the Undergraduate Program in French at the Federal University of Minas Gerais. Márcia Arbex has a PhD in French Literature and Civilization from Université Sorbonne Nouvelle - Paris 3 (1992) and a Bachelor in Literature - Portuguese/French from the Federal University of Rio de Janeiro (1984). She has two postdoctoral degrees from Université Paris 7 - Denis Diderot (2003) and from Federal University of Rio de Janeiro (2010).

ii PhD Student in Literary Studies at Rio de Janeiro State University (UERJ, in Portuguese). CAPES Scholar. thayanevercosa@ hotmail.com

iii Master's Student in Literary Studies at Rio de Janeiro State University (UERJ, in Portuguese). CAPES Scholar. lais.alvessouza@yahoo.com.br
} 
We are delighted to publish this interview with Professor Márcia Arbex, who promptly accepted our invitation and was very receptive to the questions we had presented to her. We would like to emphasize that it was a pleasure to come to know more about the admirable trajectory of our interview, and we certainly learned a lot from her production and reflections on such a fundamental subject not only for literature students but also for those of other fields. We wish you all a pleasing reading.

\section{PALIMPSESTO}

1) For over two decades, you have been coordinating different research projects on the relationship between literature and other arts, and have published several essays on the subject matter. Considering your solid production in this area, we would like to know: (a) how did you become interested in researching the relationship among different arts?; (b) what is the current situation of intermedial studies in Brazil and abroad?; (c) in your opinion, which authors are unavoidable today for those who wish to delve into the subject?

\section{MÁRCIA ARBEX}

First, I would like to thank the publishers for inviting me for this interview and for carefully reading some of my articles.

At the end of my undergraduate degree in Literatures, which I attended at UFRJ, I tried to elaborate a postgraduate research project focusing on the interrelation between literature and arts, as I was interested in these two forms of artistic expression. Thus, my thesis investigated the function of writing in the visual arts during the historical avantgarde period, with the title: Da imagem da letra à picto-poesia: estudo sobre a função da escrita nas artes visuais (1910-1930), a thesis defended at the Université de Paris 3 and revalidated by UFRJ in the area of Semiology. Later, as a professor in the Postgraduate Program in Literary Studies at UFMG and as a CNPq researcher, I developed several projects in this same line, called Literature and Other Arts - today, Literature, Other Arts and Media -, to encompass the different modalities of dialogue between literature and the visual arts. I began investigating the iconicity of writing and the visuality of words in the visual arts, the intericonicity and collage, artists' writings, to then study the presence of the image in literature, the processes of intersemiotic 
transposition whether as illustration, iconotext, or ekpharis; finally, I became interested in artists' books, the object-books, and other forms of interartistic dialogue.

Those researchers necessarily take into account the historical debate about the dimensions of the visible and the legible, as well as its long-standing theorization. The studies on intermediality stem from this long tradition that goes back to the doctrine of ut pictura poesis, to Diderot's art criticism in the Salons and the discussion on the boundaries between painting and poetry inaugurated by Lessing, to the "correspondences between the arts" and the semiological studies on the expanded notion about Text, up to Interarts Studies. In the $20^{\text {th }}$ century, the revision of the very concept of art led to the revision of the statute of the image in its relation to words. Thus, beyond the comparison between painting and poetry, beyond the paragon, new types of literary and aesthetic expression excluded from the comparative interarts studies until then began to be investigated for their importance as contemporary cultural phenomena and for the challenges they pose for the reception.

In fact, studies on intermediality have been consolidated in Brazil through events, research dissemination, publication of books and thematic dossiers in journals, and translations of reference texts. Researchers who look into the intermedial phenomena open perspectives for the inclusion of a wider aesthetic and technological field, such as television and digital media, performance art, digital poetry, for example, and not only the so-called conventional arts. Therefore, the growing number of artistic and literary productions marked by hybridity, by the mixture of genres, by the awareness of their materiality, continuously requests a revision of concepts and theoretical and methodological approaches. In fact, if we consider that there are no "pure" media, and that this phenomenon of hybridity has always existed, for the analysis of creative processes, the question that arises is of a methodological and theoretical order, as well as its sociological, historical and cultural implications.

There are several research centers focused on this type of subject matter with different theoretical orientations, but in some way they all have in common the study of the relationship between word and image. I can mention some of them - of which I participate - considering that the publications of its members are relevant to those who are interested in this area of investigation. In Brazil, we have Grupo Intermídia, created in 2005 with Prof. Claus Clüver's collaboration, whose production is a reference in the 
subject, and the ANPOLL'S Intermidiality working group. In my opinion, works also unavoidable are those developed by members of IAWIS (International Association of Word and Image), of CRIalt (Centre de Recherches Intermédiales sur les arts, les lettres et les techniques), of the University of Montreal, and of CEEI (Centre d'Étude sur l'Écriture et l'Image), an international research network on writing, typography, and illustration. We also maintain contact with researchers from foreign universities such as Freie Universität Berlin, Florida University, and Linnæus University in Sweden¹.

\section{PALIMPSESTO}

2) In the essay "A imagem escrita da infância" (2006), you comment on La mer écrite [The written sea], "a small album composed of texts and photographs, the first ones by Marguerite Duras, the photos by Hélène Bamberger" (ARBEX, 2006, p. 109). Before one of the photographs, you emphasize the manner how text and images are positioned side by side: "In this album, the texts on the left and the photographs on the right occupy the center of the given pages, not going beyond the invisible limits of the layout. There is no primacy of one over the other - both are presented simultaneously and transform the once hierarchical relationship between word and image. The photograph does not illustrate the text, and the text is not commenting on the photograph: they complete each other" (Ibid., p. 110). We could compare La mer écrite with one of Maureen Bisilliat's most famous works - A João Guimaraes Rosa (1969). In this book, the author photographs Minas Gerais' backlands and combines her photos with excerpts from Grande Sertão: Veredas [The devil to pay in the backlands] (1956), which are placed next to the images (sometimes below, above, or beside them), similar to what is presented in La mer écrite. Considering that Bisilliat's text was incited by the reading of the novel, with citations of passages not conceived originally to the images, is it possible to think that there is also a relationship of complementarity and equality between the images and the excerpts? Would the author's inspiration by the reading of the novel imply a hierarchy between text and image? Would A João Guimarães Rosa be a case of intersemiotic translation?

\section{MÁRCIA ARBEX}

In both cases we can speak of photoliterature, but from the point of view of production, the works seem distinct to me. Marguerite Duras and Hélène Bamberger initially carried out a collaborative work during the summer of 1980 in Trouville; indeed, the names of the writer and the photographer appear on the book's cover. 
Regarding the album A João Guimarães Rosa, although the Brazilian writer initially contributed to the project - the presentation of the book on the publisher's website states that Bisilliat showed the photos to Rosa when she returned from her trips through the backlands, and Rosa wrote down the names of places and people on the back of the photos $^{2}-$, it does not seem to me that this was the same type of collaboration in the production of the work. In my opinion, the fact that Bisilliat's photo essay was motivated by the reading of Guimarães Rosa's novel can be interpreted as an intersemiotic transposition, from the verbal to the visual, since the text precedes the images and the photos were motivated by the novel. Regarding the presence of quotation taken from The devil to pay in the backlands, I believe it is necessary to take into consideration other information about the production of the work, whether through interviews with the photographer, paratexts such as prefaces, or other material that allows us to evaluate, for example, how the choice of literary excerpts was made. We thus could have access to the creative process of the work. Furthermore, we could consider the role of the editor, their participation in the conception of the editorial work, the graphic choices, the book's format, the arrangement of photos and images everything involving the materiality of the book object.

From the point of view of reception, however, one can consider that the complementary relationship we observe in Duras and Bamberger's book is similar to Bisilliat's. The reader has in his hands a hybrid object (a combination of media) in which text and image are gathered in the same support, and they simultaneously occupy the page, given the chosen graphic layout, but maintain their media differences. Thus, there is a dialogue between what is seen and what is read, a transit between the visible and the legible, even though the image has a greater impact due to its dimensions in relation to the space occupied by the text. Rosa's quotations are not comments on the photographs, nor are the photographs illustrations of the excerpts from the novel in the sense that the word "illustration" had until the beginning of the $19^{\text {th }}$ century, that is, an "image of the book" intended to accompany the printed text, of a functional nature, aiming to explain, comment, or clarify. This hierarchical relationship was called into question, transgressed since the end of the $19^{\text {th }}$ century - precisely by artists and poets who began to work together, giving rise to beautiful productions, the "dialogue books", in Michael Butor's or Yves Peyré's words, the "double books", as Christin says, in 
which the interval and the oscillation between the visible and the legible are also creators of meaning.

\section{PALIMPSESTO}

3) In your essay "As metáforas picturais de René Magritte" (2007), commenting on "the distance between the representation of a thing and the real thing itself, understanding that there is indeed no relation between a real object and the image (or the name) representing it, the relation is arbitrary and conventional" (ARBEX, 2007, p. 157-8), you ponder that "[the] painting that better translates this idea is La Trahison des images [The Betrayal of Images], in which a caption (Ceci n'est pas une pipe) accompanies the realist-looking image of the object 'pipe', emulating the model found in textbooks" so that "the content of the inscription that seems at first to contradict the image showing a pipe is in fact intended to highlight the fact that images are not tangible like the language" (Ibid., 158). Since its creation, La Trahison des images has become a source of inspiration for various pastiches with the most distinctive critical purposes. There seems to be a subgroup of these pastiches, which we could classify as political: in these pastiches, the caption "Ceci n'est pas un président" accompanies the photo of a president. Donald Trump, Michel Temer, Jair Bolsonaro, and Nicolás Maduro are some figures referenced in such pieces. In this circumstance, could we consider that they still aim at evidencing that "images are not tangible like the language"? By recapturing a classic work that questions the representational character of the image and imbuing it with a political dimension with critical intent, what new meanings are added to it? Does the wide diffusion of this kind of pastiche affect the critical sense of the original work in any way?

\section{MÁRCIA ARBEX}

In fact, this canvas is one of Magritte's best-known pieces, the one that has generated the most re-readings since its creation in the late 1920s. Michel Foucault's study on the different versions of La Trahison des images, the fruit of the exchanges between the philosopher and the artist around issues that concern them, "words and things", has become a reference text since its publication in 1973, a fact that contributed a lot to this resumption of the inscription "This is not a pipe", almost an aphorism, to serve the most diverse purposes, whether artistic, political, or humorous. Many interpretations have been made about this apparently paradoxical relationship between the inscription and the image in this painting, so there is no need to take them up again 
here. But it is important to remember the context in which the work was produced and Magritte's concerns at the time, when he practiced this method of associating words to figures so to create a disturbing poetic effect, a strangeness between the perception of objects and the way they are named. This further highlights the issue, dear to Magritte, of resemblance and the deconstruction of the conventions of representation. Magritte works on this canvas as a philosopher of language and, why not, a philosopher of the image. At this point, the pastiche's ironic retaking of the famous phrase "This is not a pipe", transposed to different contexts, updates its critical, deconstructive aspect, but in other terms since the issue is no longer the tangibility of the image or language. In my view, the political implications arising from the critical resumption of the principle of the text-image association in fact extend the reach of the original work.

\section{PALIMPSESTO}

4) In today's classic essay "The reality effect" (1968), Rolland Barthes differentiates between the modern and ancient verisimilitude, showing with a contrastive movement that the ancient description was marked by an aesthetic purpose, while the modern one would be submitted to a referential, realistic purpose. However, when analyzing Madame Bovary, a work by a reputed realist author, he notices how Flaubertian description is marked by an intersection of aesthetic and referential purposes. It does not seem an overstatement to say that we can find the same coexistence between the different types of descriptions in, for example, Barren Lives, by Graciliano Ramos, considered by Alfredo Bosi (2015, p. 431) as a "masterpiece of formal sobriety". Would the presence of aesthetic descriptions ("ekphrastic", according to Barthes) in realist works be one case of correspondence between literature and painting? How could this Barthesian issue be repositioned in terms of contemporary intermedia studies?

\section{MÁRCIA ARBEX}

There is no doubt that ekphrasis is a recurring topos in the studies of correspondences between literature and painting, and a relevant operator in research on text and image, especially when it takes an artistic work as its object. As a rhetorical exercise, as is well known, ekphrasis has its origins in antiquity but it is still the subject matter of reflection by researchers, so that the bibliography on this subject is very vast, and involves sometimes controversial terminological and theoretical issues. I recently 
published an article about the presence of descriptions of works of art, also called "tableaux d'auteurs" in contemporary French-language narratives; in the courses I teach in the Postgraduate Program in Literary Studies (Poslit), this topos is also the object of analyses, and it also appears in the program of many events in the field ${ }^{3}$.

Ekphrasis, a Greek term defined by rhetorical manuals as a trope, one of the figures of thought, is equivalent to descriptio, Latin for "description". Very briefly, we can say that ekphrasis is initially a rhetorical description technique whose purpose is to detail something in words, in a meticulous way, whether the description is of real or fictional people, actions, places, animals, or objects. However, studies and translations from the $18^{\text {th }}$ and $19^{\text {th }}$ centuries favored the resumption of the term in the sense of "literary description", which resulted in the redefinition of the term, started to designate even more specifically a "literary description of a work of art", or even a "transposition d'art", highlighting the relationship between literature and the visual arts. Roland Barthes participates in this debate in the field of narrative theories of the $20^{\text {th }}$ century. He defends description as a capital element of diegesis, particularly in the $19^{\text {th }}$-century authors, such as Flaubert, mentioned above. In opposition to a conception that considers description as "useless detail", ornamental, for threatening the coherence of the work, Barthes proposes a more modern and semiological view: detail is an important element that participates in the creation of a "real effect" that gives description a historical dimension, beyond its aesthetic function only. I remember that Roland Barthes in $S / Z$ had already proposed to eliminate the difference between literature and painting, which would be purely of material medium, to renounce the plurality of arts to affirm the "plurality of texts", as a first step to introduce the discussion on artistic objects as objects of culture in the field of Comparative Studies. This paradigm shift had great repercussions for the understanding of ekphrasis.

By the way, Scholars in the field of intermediality have been more and more dedicating themselves to this long-tradition notion, including it among the procedures of media transformation. This happens because ekphrasis is considered a transmediatic phenomenon, and although painting is the main source for literary descriptions of works of art, there is a growing concern to encompass other types of artistic manifestation, such as non-representational paintings, photography, installation, architecture, music, 
and cinema. Beyond the field of Interarts Studies, the study of ekphrasis expands itself to objects composed in different media, including today's digital media ${ }^{4}$.

\section{PALIMPSESTO}

5) "Sobrevivências da imagem na escrita: tempo e memória em narrativas contemporâneas", your most recent research project, started in 2020, is described as a project "of a transdisciplinary nature, [that] aims at articulate theoretical research on the interaction between writing and image, literature and arts, literary productions by contemporary authors, mainly French-speaking ones, such as Michel Butor, Jean-Marie Gustave Le Clézio, Patrick Modiano, Michel Houllebecq, Pascal Quignard, and Georges Perec". Which knowledge fields are involved in this transdisciplinary project? How do the notions of text and image articulate in the project? What types of research tools do you intend to produce with the development of the project? Is there an intention to extend the project to contemporary authors of other languages?

\section{MÁRCIA ARBEX}

My most recent project involves the areas of Comparative Literature, Literary Theory, French Literature, but also History and Philosophy of Art, Anthropology, History of Writing, and Publishing. This research examines the interaction among the arts in order to constitute a theoretical framework for the analysis of contemporary narratives transiting through this border zone between writing and image, and to produce research tools that can indeed be used in analyses of contemporary authors in general, and not only of French Literature. I hypothesize that, for certain authors or in certain works, the image, anchored in different media and on different supports, becomes a privileged media foundation of writing. The work of Alain Robbe-Grillet or that of Michel Butor, on which I have focused more recently, is exemplary in this regard $^{5}$. Michel Butor's production is particularly significant. From a mapping of the modalities of the relationship between writing and image in his vast work, we identify several iconotexts: the descriptions of works of art in novels, typographical games, photoliterature, and dialogue books made in collaboration with artists, having as a horizon the modes of survival of the image in writing. The study starts from the notions of "media foundation" by Walter Moser; "iconotext", by Liliane Louvel; "iconicity of writing" and "screen thinking", proposed by Anne-Marie Christin and by theoreticians 
who also understand writing as a mixed entity formed by the verbal and the visual; I also resort to Georges Didi-Huberman's conception of image and time, among other theoreticians. The notions of writing and image are the main operators for this study, besides the concepts of collage and montage, which are relevant critical devices to understand not only the compositional techniques of texts, but their effects on visual knowledge, of the action of multiple temporalities involved in the survival of the image as a fact of memory, be it individual or collective.

\section{References}

ARBEX, Márcia. A imagem escrita da infância. Revista do CESP, Belo Horizonte, v. 26, n. 35, p. 107-123, jan./jun. 2006. Disponível em: http://www.periodicos.letras.ufmg.br/index.php/cesp/article/view/6651/5651. Acesso em: 27 jun. 2021.

ARBEX, Márcia. As metáforas picturais de René Magritte. Letras, Santa Maria, n. 34, jun. 2007. Disponível em: https://periodicos.ufsm.br/letras/article/view/11945. Acesso em: 3 jul. 2021.

BARTHES, Roland. O efeito de real. In: . O rumor da língua. Tradução Mário Laranjeira. São Paulo: Brasiliense, 1988. p. 158-165.

BOSI, Alfredo. Tendências contemporâneas: Graciliano Ramos. In: História concisa da literatura brasileira. 50. ed.. São Paulo: Editora Cultrix, 2015. p. 428-432.

\footnotetext{
${ }^{1}$ There are countless publications on the subject in Brazil. I suggest the page of the Grupo Intermídia where you can find a non-exhaustive list of those texts:

http://www.letras.ufmg.br/padrao_cms/?web=intermidia\&lang=1\&page=2657\&menu=1685\&tipo=1. For those who may be interested, I suggest the pages of these research centers abroad:

https://www.iawis.org/; https://crialt-intermediality.org/eng/; https://ceei.hypotheses.org/. Also see ARBEX, Márcia (Org.). Poéticas do Visível : ensaios sobre a escrita e a imagem. Belo Horizonte : FALE/PÓSLIT, 2006.

${ }^{2}$ https://ims.com.br/2018/10/04/fotografia-e-literatura-nos-livros-de-maureen-bisilliat-a-joaoguimaraes-rosa/.

${ }^{3}$ See ARBEX, M. Contemporary tableaux d'auteurs in Michel Houellebecq's and Michel Tournier's Novels. In: Text - Image - Music: Crossing the Borders. Intermedial Conversations on the Poetics of Verbal, Visual and Musical Texts, ed. By Andrzej Pawelec and Grzegorz Szpila. Peter Lang Edition, 2020 .
} 
4 For the discussion on ekphrasis, among many other articles, see CLÜVER, Claus. "Ekphrasis Reconsidered: On Verbal Representations of Non-Verbal Texts." In: Lagerroth, Ulla-Britta, Hans Lund and Erik Hedling (eds.), Interart Poetics: Essays on the Interrelations between the Arts and Media. Amsterdam, Atlanta: Rodopi, 1997, p. 19-33; Webb, Ruth. "Ekphrasis Ancient and Modern: The Invention of a Genre." Word \& Image: A Journal of Verbal/Visual Enquiry, 15: 1, 1999; Vouilloux, Bernard. Tableaux d'auteurs. Après l'Ut pictura poesis. Saint-Denis: Presses Universitaires de Vincennes, 2004.

${ }^{5}$ See ARBEX, M. Sobrevivências da imagem na escrita: Michel Butor e as artes. Belo Horizonte: Editora Relicario, 2020; ARBEX, M. Alain Robbe-Grillet e a pintura: jogos especulares. Belo Horizonte: Editora UFMG, 2013. 